\title{
CHALLENGES FACED BY ART AND TECHNOLOGY ON SOCIAL AND ETHICAL GROUNDS
}

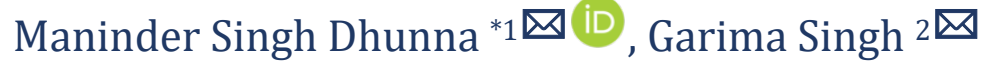 \\ ${ }^{* 1}$ Research Scholar, Graphics Department, Indira Kala Sangit Vishwavidyalaya, Khairagarh, \\ Chhattisgarh, India \\ 2 MBA, Bhilai Institute of Technology Durg, Chhattisgarh, PGCDM, Symbiosis Centre of Distance \\ Learning, Pune, India
}

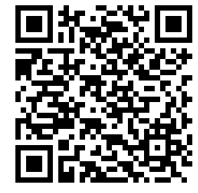

DOI: https://doi.org/10.29121/granthaalayah.v9.i3.2021.3489

Article Type: Research Article

Article Citation: Maninder Singh Dhunna, and Garima Singh. (2021). CHALLENGES FACED BY ART AND TECHNOLOGY ON SOCIAL AND ETHICAL GROUNDS. International Journal of Research -

GRANTHAALAYAH, 9(3), 288-290. https://doi.org/10.29121/granthaa layah.v9.i3.2021.3489

Received Date: 03 February 2021

Accepted Date: 31 March 2021

Keywords:

Art and Technology

Challenges

Art Ethics

Social Impact

\section{ABSTRACT}

The use of technologies in art is at its peak and it wouldn't be wrong to state that the blend of technology and art has become the strongest factor for shaping the educational and artistic landscape. From reviving modern art, technology acts as an influential path for artists to create something unique. Different genres of art also merge with technology and give rise to pieces of work that reflect exclusiveness. It offers a powerful connection paralleled with human endeavor. These digital technologies instill smart thinking, smart concepts, and methods of creation in artists. However, the study explores the challenges faced by art and technology in terms of social and ethical platforms. To study the challenges faced by art and technology, we will also discuss opportunities it provides to artists and the art industry. To address the research paper, the study adopts a quantitative method to answer the research objectives.

\section{INTRODUCTION}

\subsection{BEAUTY OF ART AND TECHNOLOGY}

The Intersection of art and technology has created a beautiful world. The combination of art and technology always gives rise to different aspects. A lot of data, studies, and research labeled this combination as controversial at one time and claims it to be an undisputed relationship in others. Therefore, the amalgamation of art and technology can be termed as complex. They have evolved alongside each other to originate new techniques to portray new ideas on the canvas of artists. Innovations in technology have progressively affected the world of art and they will keep on doing the same in coming years too. These two fields might look unlike each other yet have more in common. Both the areas possess experimental nature which demands a good amount of creativity to enhance their overall offering. 
In addition to this, modern technology blessed many artists by introducing artists to evolutionary tools which have lately become a helping hand for them. Programs such as photoshop helped artists to explore their creative freedom to the next level.

The combination of advanced art systems and artists gives rise to new methods, algorithms, and prototypes in opening new horizons. The same connection endows a breeding ground for unique projects which eventually cater to the need of art and artists in order to survive in the digital era. The exterior walls of these art systems have established a professional network and an effective way of communication that helps artists to improve the quality of work and spread their artistic message into the world. It lessens the production time and offers a paradigm to explore art beyond the traditional canvas.

Artists can choose whether they want to resist technological advances in pursuit of true connection to nature or embrace innovations to explore something unique. Nowadays, most artists have switched their mode of working from traditional to digital and are embracing modern art techniques because it has a lot to offer. Therefore, it has become an unbreakable chain that artists cannot resist. However, in a nutshell, it has shortened their average effortreward timespans.

\subsection{CHALLENGES FACED BY ART AND TECHNOLOGY}

Even after presenting numerous benefits to the art industry, artists, and society, the combination of art and technology together face some challenges too. If we talk about the challenges faced by it on social grounds, a certain amount of rejection can be seen regarding the blend of art and technology. People view art in technology in an inauthentic way, as for them the work doesn't seem to be original and genuine. Because of this lethal combination many famous art pieces are being reproduced and changed by hackers and designers at an alarming rate which is also ethically wrong. The painting of Monalisa is a good example, as we can see it has been created and reproduced in many versions. The constant alteration of Monalisa painting has taken away its freshness and originality and sadly, it has become common. It is also said that this kind of art can snatch the creative aspect of art. From an individual point of view, technology is an assistant for artists has dampened the flame of creativity as their work is largely based on technical abilities instead of their own.

Another problem that arises on social and ethical grounds is the problem of 'Fake'. Fakes and frauds are everywhere and the art industry is no exception. The weak infrastructure of art makes it possible. According to Sharan Apparao, owner of Chennai-based Apparao Gallery, every year 20- 30 fakes of important paintings and 50100 fakes of lesser important paintings enter the market. We can also consider the case of Jamini Roy's son who sold fakes of his father along with forged signatures. The fraudster's main aim is to trap foolish buyers in their trap in the name of selling them famous artwork. It can also be done online and people easily become the victim of forgery. Deprived of proper documentation of artwork makes it easier for fake markets to flourish in India. Steps must be taken about the virtual absence of the relevant data.

Due to technological advancement, one can easily edit photographs, music, painting, and other contents. In a world full of editing and manipulation it has become difficult to identify the real one.

One of the challenges faced by artists and the art industry due to technological advancement is the problem of copycats. It's discouraging to see great designs made by artists are copied. It is

frustrating for an artist when their years of hard work and effort is copied. Theft of artwork is a shortcut embraced by evil minds to make money by imitating the artwork of an artist and then selling it at a higher price. These kinds of incidents, usually malign the reputation of art in the eyes of individuals. Some artists shout out the issue of their art being copied to their social media accounts to seek justice but unfortunately, there is no strict law for this issue.

\section{CONCLUSION}

No doubt the art industry is going through a drastic transformation by embracing modern technologies. Even if these two disciplines have a lot in common but it also has some downsides which give birth to challenges. Challenges faced by art and technology on social and ethical grounds are discussed above and light has been shed on the sectors where the problem arises. We came to know that the art industry is facing problems of forgery, scams, plagiarism, manipulation of art. Non-acceptance of technology in art or digital art in individuals and society is another downside. 


\section{SOURCES OF FUNDING}

This research received no specific grant from any funding agency in the public, commercial, or not-for-profit sectors.

\section{CONFLICT OF INTEREST}

The author have declared that no competing interests exist.

\section{ACKNOWLEDGMENT}

I would like to thanks Dr. Rabi Narayan Gupta for his guidance, I'm also grateful to my co-author Garima Singh for her support.

\section{REFERENCES}

[1] Sandrine Pelissier. (blog). How to deal with an art copycat in art business inspiration thoughts. https://paintingdemos.com/how-to-deal-with-copycats/

[2] Amy. (2017, April 17). Creativity, competition and copycat http://www.pikaland.com/2009/04/17/creativity-competition-copycats/

[3] Lori McNee. (2010, July 1). How I stopped a copycat artist on Facebook https://lorimcnee.com/how-istopped-a-copycat-artist-on-facebook/

[4] Financial express. (2004, June 20). The art of fake https://www.financialexpress.com/archive/the-art-of-thefake/107127/

[5] Roxana Boitel. (2019, June 17). How has technology affected the arts? https://inewsnetwork.net/4723/artsentertainment/how-has-technology-affected-the-arts/

[6] Elizabeth m. Grierson. (2016, Oct 11). Activating the creative arts and technology for a global digital economy provocations and challenges for a new philosophy. https://www.tandfonline.com/doi/full/10.1080/00131857.2016.1239351. 